\title{
Placental growth hormone and IGF-I in a pregnant woman with Pit-1 deficiency
}

\author{
J. Verhaeghe*`$\dagger$, M. Bougoussa§, E. Van Herck $\dagger$, \\ F. de Zegherł, G. Hennen§ and A. Igout§ \\ *Department of Obstetrics \& Gynaecology, \\ †Laboratorium voor Experimentele Geneeskunde en \\ Endocrinologie and $\ddagger$ Department of Paediatrics, \\ Katholieke Universiteit Leuven and §Laboratoire \\ d'Endocrinologie, Service de Biochimie, Université de \\ Liège, Belgium
}

(Received 1 November 1999; returned for revision 17 December 1999; finally revised 20 January 2000; accepted 21 February 2000)

\section{Summary}

The respective contributions of pituitary and placental GH to circulating IGF-I in pregnant women have not been well established. We measured the serum concentrations of placental growth hormone (PGH) and IGF-I in a woman with pit-1 deficiency before, during and after pregnancy, resulting in the birth of a healthy child (not pit-1 deficient). Both PGH and IGF-I concentrations were below the assay detection limit before and after pregnancy. During pregnancy, PGH and IGF-I levels increased steadily; the concentrations of PGH and IGF-I in late pregnancy were comparable with levels previously measured in normal pregnancies. PGH and IGF-I concentrations were strongly correlated throughout pregnancy $(r=0.90$; $\boldsymbol{P}=0.002$ ). PGH was undetectable in cord serum, whilst the IGF-I concentration was within the normal range. The findings of this case study corroborate the notion that PGH is the prime regulator of maternal serum IGF-I during pregnancy.

\section{Introduction}

Placental growth hormone (PGH) is encoded by the hGH-V gene, which forms part of the hGH gene locus on chromosome 17 (q22 to q24), consisting also of the hGH-N gene and 3 chorionic somatomammotrophin (hCS-L, hCS-A and hCS-B) genes. The hGH-N gene is expressed in the anterior pituitary,

Correspondence: J. Verhaeghe, Department of Obstetrics \& Gynaecology, U.Z. Gasthuisberg, Herestraat 49, 3000 Leuven, Belgium. Fax: + 32 16344205; E-mail: johan.verhaeghe@uz.kuleuven.ac.be whereas the hGH-V and the hCS genes are expressed in the syncytiotrophoblast of the placenta.

PGH is secreted in a nonpulsatile manner. Whereas the concentrations of PGH gradually increase during pregnancy, pituitary GH concomitantly falls to undetectable levels. PGH is thought to replace pituitary-derived GH during pregnancy; the somatogenic activity of PGH appears to be mediated by the production of IGF-I, similarly to pituitary-derived GH. Indeed, the rise in PGH concentrations is correlated with that of IGF-I in normal pregnancies, and both PGH and IGF-I levels fall rapidly after delivery (Caufriez et al., 1990; Mirlesse et al., 1993; Alsat et al., 1997).

Pituitary transcription factor 1 (pit-1) is a transcription factor necessary for the expression of the hGH-N, the PRL and the TSH genes in the pituitary (Pfäffle et al., 1999), and for the expression of the hGH-N but not the hGH-V gene in peripheral blood mononuclear cells (Melen et al., 1997). Pit-1 messenger RNA and protein have also been shown to be present in the human placenta (Bamberger et al., 1995), and rat pit-1 has been reported to bind to the distal site of the hGH-V gene (Nickel et al., 1991). In this case study, we longitudinally measured PGH and IGF-I concentrations in a pit-1 deficient woman before, during and after her second pregnancy.

\section{Patient and methods}

The woman concerned has been described previously (de Zegher et al., 1995). Briefly, this Caucasian patient is heterozygous for a point mutation in codon 271 of the pit-1 gene, with a C to T substition replacing an Arg (CTT) by a Trp (TTT). GH was administered temporarily before the age of 19 , and final height is $149.5 \mathrm{~cm}$. The woman is also hypothyroid; during her first pregnancy, thyroid replacement therapy was suboptimal, and mother and child (who was also pit- 1 deficient) were found to be severely hypothyroid at delivery/birth (de Zegher et al., 1995).

The 34-year-old patient was seen 7 and 2 months before her second pregnancy, and at regular intervals during pregnancy. Body weight increased from $61 \mathrm{~kg}$ before pregnancy (body mass index: $27.3 \mathrm{~kg} / \mathrm{m}^{2}$ ) to a maximum of $73.7 \mathrm{~kg}$ at 35 weeks. The pregnancy was characterized by oedema and paresthesiae in both hands from 12 weeks onwards, which improved thereafter to worsen again from 35 weeks. Pedal oedema was seen from 29 weeks onwards. Blood pressure was normal throughout pregnancy. Based on circulating thyroid hormone concentrations, ${\mathrm{L}-\mathrm{T}_{4}}_{4}$ therapy was increased gradually from 75 


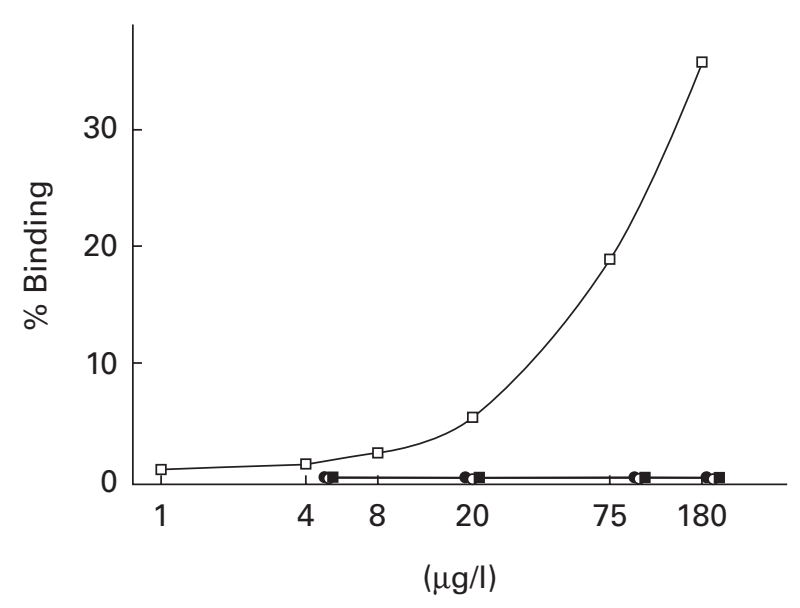

Fig. 1 Typical standard curve of the PGH two-site immunoradiometric assay for serum samples, using recombinant human PGH ( $\square$ ) as the standard, and monoclonal antibodies E8 and 7C12. There is no cross-reactivity in this assay with hGH (-), hPRL (O) or hPL $(\square)(<0.001 \%)$. Conversion to molar units: $10 \mu \mathrm{g} / \mathrm{l}=$ $0.448 \mathrm{nmol} / \mathrm{l}$. This standard curve was provided by A. Igout.

to $125 \mu \mathrm{g}$ /day before conception (to attain high-normal free $\mathrm{T}_{4}$ levels in anticipation of pregnancy) and further to a maximum of $150 \mu \mathrm{g} /$ day during pregnancy. The patient agreed orally that an additional blood tube be obtained for the purpose of this study, each time blood was sampled to monitor $\mathrm{L}_{-} \mathrm{T}_{4}$ therapy. There was no evidence of noncompliance with $\mathrm{L}-\mathrm{T}_{4}$ therapy. At 15 weeks of pregnancy, the patient underwent an amniocentesis, and the molecular findings indicated that the fetus was not carrying the maternal pit-1 mutation. A healthy girl was born by elective repeat caesarean section at 38.6 weeks, with birth

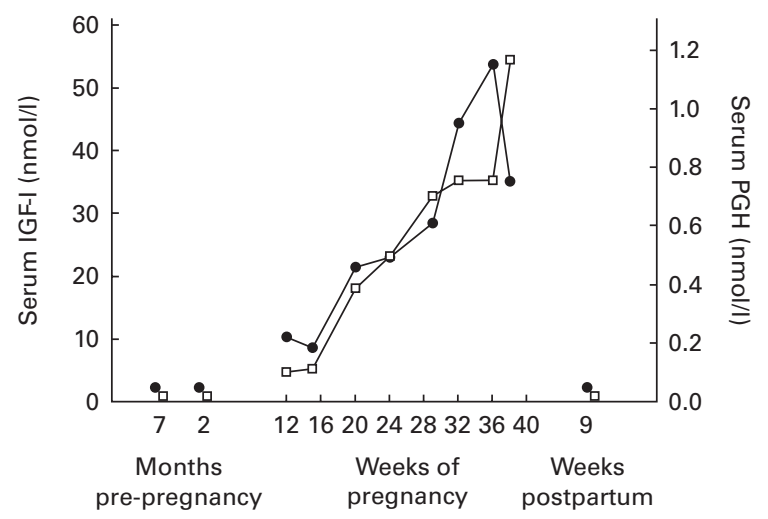

Fig. 2 Serum PGH $(\square)$ and IGF-I $(\bullet)$ concentrations in a patient with pit-1 deficiency before, during and after pregnancy. PGH was undetectable before and after pregnancy, while IGF-I concentrations were far below the detection limit of the assay. During pregnancy, there was a steep rise in both PGH and IGF-I concentrations, with a strong correlation $(r=0.90 ; P=0.002)$ between both parameters. weight $3230 \mathrm{~g}$ (between 50th and 75th percentile, according to the Flemish reference charts), length $49 \mathrm{~cm}$ and head circumference $34 \mathrm{~cm}$. Cord blood was sampled from the umbilical artery after cord clamping. Because lactogenesis failed after the first pregnancy (PRL levels were undetectable), breast feeding was not attempted. The patient was seen 9 weeks after delivery, and the $\mathrm{L}-\mathrm{T}_{4}$ dose was lowered again.

PGH was measured using a two-site immunoradiometric assay. Recombinant human PGH was used as the standard (Igout et al., 1993), and monoclonal antibodies E8 and 7C12 were used in a ${ }^{125}$ I-labelled sandwich immunoassay (Igout \& Hennen, 1997). The molecular mass of PGH is $22320 \mathrm{Da}$ (Igout et al., 1993). In this assay, the cross-reactivity of hGH, hPRL and hPL is $<0.001 \%$ (Fig. 1). The intra-assay coefficients of variation were $5 \cdot 1,3.0$ and $5.5 \%$, for samples with PGH concentrations of $20.5,49.5$ and $73.5 \mu \mathrm{g} / \mathrm{l}$ (low, medium and high), respectively; the interassay coefficients of variation were 5.5, 5.0 and $7.9 \%$, respectively. The detection limit is about $0.2 \mu \mathrm{g} / \mathrm{l}(9 \mathrm{pmol} / \mathrm{l})$ for serum samples. After acid ethanol extraction, IGF-I was measured by radioimmunoassay using recombinant human IGF-I (rhIGF-I) as the standard and a polyclonal antiserum raised in guinea pigs, as described previously (Verhaeghe et al., 1992, 1993). The detection limit of the IGF-I assay is about $50 \mathrm{pg} / \mathrm{tube}$, or $35 \mu \mathrm{g} / \mathrm{l}(4.6 \mathrm{nmol} / \mathrm{l})$ for routine serum samples.

\section{Results and discussion}

Figure 2 demonstrates that the serum concentrations of PGH and IGF-I were undetectable and far below the detection limit, respectively, in this pit-1 deficient woman, both before (two time points) and after pregnancy. For IGF-I, the results were 7 and $3 \mu \mathrm{g} / \mathrm{l}$ before pregnancy, and $1 \mu \mathrm{g} / \mathrm{l}$ after pregnancy (the detection limit of routine assay is $35 \mu \mathrm{g} / \mathrm{l}$ ); PGH was undetectable in the three samples. There was a steady increase in the levels of PGH and IGF-I in the course of pregnancy. The maximum level of PGH was comparable with previous data in normal pregnancies (Mirlesse et al., 1993). For IGF-I, the maximum concentration was $53.7 \mathrm{nmol} / \mathrm{l}(411 \mu \mathrm{g} / \mathrm{l})$, which is 3 $\mathrm{SD}$ above the mean previously measured with the same assay in 36 nonpregnant women of 30-40-year-old $(31.3 \pm 7.6 \mathrm{nmol} / \mathrm{l}$, mean \pm SD) (Bouillon et al., 1995). Mirlesse et al. (1993) reported that mean IGF-I levels rose from 20 to $26 \mathrm{nmol} / 1$ $(150-200 \mu \mathrm{g} / \mathrm{l})$ in the first half of pregnancy to $43.4 \mathrm{nmol} / \mathrm{l}$ $(332 \mu \mathrm{g} / \mathrm{l})$ at term. Thus, the IGF-I concentrations in late pregnancy in this patient are in line with previous findings in normal pregnancies; consequently, the rise in IGF-I levels during early pregnancy was much steeper compared with normal pregnancies. Interestingly, the patient developed symptoms of oedema and paresthesiae in both hands at 12 weeks when IGF-I levels started to rise, and worsened at 
35 weeks when IGF-I values were maximal. Oedema and paresthesiae (carpal tunnel-like symptoms) are known sideeffects of the use of rhIGF-I therapy (Jabri et al., 1994); rhIGF-I has been shown to increase forearm blood flow (Copeland \& Nair, 1994). PGH and IGF-I concentrations were strongly correlated during pregnancy $(r=0.90 ; P=0.002 ; n=8)$, a finding that confirms the notion that PGH regulates maternal serum IGF-I concentrations during pregnancy (Caufriez et al., 1990; Mirlesse et al., 1993).

The IGF-I concentration in cord serum was $9.7 \mathrm{nmol} / \mathrm{l}$, which is within the normal range (mean $\pm 1 \mathrm{SD}$ of 52 girls at 38 weeks: $8.4 \pm 3.0 \mathrm{nmol} / \mathrm{l}$ ) (Verhaeghe et al., 1993). PGH was undetectable in cord serum, confirming previous data (Frankenne et al., 1988).

In conclusion, serum PGH levels and IGF-I levels increased steadily during pregnancy in a woman with pit-1 deficiency, and there was a strong correlation between both. This case study shows that PGH is the prime regulator of maternal serum IGF-I during pregnancy.

\section{Acknowledgements}

This work was supported in part by a grant from the 'Région wallonne' (2640). The authors thank R. van Bree, R. Pijnenborg, L. Vercruysse and K. Rummens for their advice and help.

\section{References}

Alsat, E., Guibourdenche, J., Luton, D., Frankenne, F. \& Evain-Brion, D. (1997) Human placental growth hormone. American Journal of Obstetrics and Gynecology, 177, 1526-1534.

Bamberger, A.-M., Bamberger, C.M., Pu, L.-P., Puy, L.A., Peng Loh, Y. \& Asa, S.L. (1995) Expression of pit-1 messenger ribonucleic acid and protein in the human placenta. Journal of Clinical Endocrinology and Metabolism, 80, 2021-2026.

Bouillon, R., Bex, M., Van Herck, E., Laureys, J., Dooms, L., Lesafre, E. \& Ravussin, E. (1995) Influence of age, sex, and insulin on osteoblast function: osteoblast dysfunction in diabetes mellitus. Journal of Clinical Endocrinology and Metabolism, 80, 1194-1202.

Caufriez, A., Frankenne, F., Englert, Y., Golstein, J., Cantraine, F., Hennen, G. \& Copinschi, G. (1990) Placental growth hormone as a potential regulator of maternal IGF-I during human pregnancy. American Journal of Physiology, 258, E1014-E1019.
Copeland, K.C. \& Nair, K.S. (1994) Recombinant human insulin-like growth factor-I increases forearm blood flow. Journal of Clinical Endocrinology and Metabolism, 79, 230-232.

Frankenne, F., Closset, J., Gomez, F., Scippo, M.L., Smal, J. \& Hennen, G. (1988) The physiology of growth hormones (GHs) in pregnant women and partial characterization of the placental $\mathrm{GH}$ variant. Journal of Clinical Endocrinology and Metabolism, 66, 1171-1180.

Igout, A. \& Hennen, G. (1997) The human placental growth hormone variant. A review. Trophoblast Research, 10, 345-352.

Igout, A., Van Beeumen, J., Frankenne, F., Scippo, M.-L., Devreese, B. \& Hennen, G. (1993) Purification and biochemical characterization of recombinant human placental growth hormone produced in Escherichia coli. Biochemical Journal, 295, 719-724.

Jabri, N., Schalch, D.S., Schwartz, S.L., Fischer, J.S., Kipnes, M.S., Radnik, B.J., Turman, N.J., Marcsisin, V.S. \& Guler, H.-P. (1994) Adverse effects of recombinant human insulin-like growth factor I in obese insulin-resistant type II diabetic patients. Diabetes, 43, 369374.

Melen, L., Hennen, G., Dullaart, R.P.F., Heinen, E. \& Igout, A. (1997) Both pituitary and placental growth hormone transcripts are expressed in human peripheral blood mononuclear cells (PMBC). Clinical and Experimental Immunology, 110, 336-340.

Mirlesse, V., Frankenne, F., Alsat, E., Poncelet, M., Hennen, G. \& Evain-Brion, D. (1993) Placental growth hormone levels in normal pregnancy and in pregnancies with intrauterine growth retardation. Pediatric Research, 34, 439-442.

Nickel, B.E., Nachtigal, M.W., Bock, M.E. \& Cattini, P.A. (1991) Differential binding of rat pituitary-specific nuclear factors to the 5 -flanking region of pituitary and placental members of the human growth hormone gene family. Molecular and Cellular Biochemistry, 106, 181-187.

Pfäffle, R.W., Blankenstein, O., Wüller, S. \& Kentrup, H. (1999) Combined pituitary hormone deficiency: role of Pit-1 and Prop-1. Acta Paediatrica, 433, 33-41.

Verhaeghe, J., Suiker, A.M.H., Visser, W.J., Van Herck, E., Van Bree, R. \& Bouillon, R. (1992) The effects of systemic insulin, insulin-like growth factor I and growth hormone on bone growth and turnover in spontaneously diabetic BB rats. Journal of Endocrinology, 134, 485492.

Verhaeghe, J., Van Bree, R., Van Herck, E., Laureys, J., Bouillon, R. \& Van Assche, F.A. (1993) C-peptide, insulin-like growth factors I and II, and insulin-like growth factor binding protein-1 in umbilical cord serum: correlations with birth weight. American Journal of Obstetrics and Gynecology, 169, 89-97.

de Zegher, F., Pernasetti, F., Vanhole, C., Devlieger, H., Van den Berghe, G. \& Martial, J.A. (1995) A prismatic case. The prenatal role of thyroid hormone evidenced by fetomaternal Pit-1 deficiency. Journal of Clinical Endocrinology and Metabolism, 80, 3127-3130. 